ROCZNIKI HUMANISTYCZNE

Volume 66, issue $4-2018$

SELECTED PAPERS IN ENGLISH

DOI: http://dx.doi.org/10.18290/rh.2018.66.4-3e

\title{
BEATA GAWROŃSKA-ORAMUS
}

\section{FICINO AND SAVONAROLA TWO FACES OF THE FLORENCE RENAISSANCE}

At the end of the $15^{\text {th }}$ century, Renaissance Florence experiences an extraordinary period of fascination with the person and teachings of Girolamo Savonarola. The golden Medici century was followed by the Bruciamenti delle vanità, during which many objects of wealth, musical instruments and priceless works of art were committed to the flames. A year later, Savonarola himself, who inspired those "bonfires of vanities," died at the stake in Piazza della Signoria. ${ }^{1}$

The reaction to the secularization of the Medici times was not based on simple negation. Savonarola operated in an environment permeated by refined Renaissance culture, with its love of antiquity and philosophy, during the flourishing period of the Platonic Academy.

The analysis of the relationship between the main intellectual and spiritual authority of the Platonic Academy, Marsilio Ficino and Savonarola, is possible by comparing some aspects of the activities of each antagonist and a description of the growth of their conflict, based on selected sources, and studies of the subject. ${ }^{2}$

Beata GawrońSKa-Oramus, M.A.-doctoral procedure open at the Institute of Arts of the Polish Academy of Sciences in Warsaw on: Florentine Painting Between Ficino and Savonarola; e-mail: beata.gawronska-oramus@wp.pl

The Polish version of the article was published in Roczniki Humanistyczne vol. 61, issue 4 (2013).

${ }^{1}$ Bruciamenti delle vanità took place at the end of the carnival in the years 1497 and 1498. Girolamo Savonarola was burned at the stake on 23 May 1498. See Maurilio ADRIANI, Firenze sacra (Firenze: Nardini, 1990), 169-170; Adam Ostrowski, Savonarola (Warszawa: Państwowy Instytut Wydawniczy, 1974), 230-235; Jacob BURCHARDT, Kultura Odrodzenia we Wtoszech (Warszawa: Państwowy Instytut Wydawniczy, 1991), 291-292; John R. HaLE, Encyclopaedia of the Italian Renaissance (London: Thames and Hudson, 1989), 291.

${ }^{2}$ The text of this article is based on a paper on the same subject: Ficino and Savonarola. Two Faces of Florentine Renaissance, delivered at the Polish Academy of Learning on 13 October 2011. 
The fundamental source texts are the following: Savonarola, Prediche e scritti; Guida Spirituale -Vita Cristiana; Apologetico: indole e natura dell'arte poetica; De contemptu mundi and Ficino's letters and Apologia contra Savonarolam, as well as Pico della Mirandola's De hominis dignitate.

The activity and philosophical and aesthetic views of Marsilio Ficino (1433-1499) were discussed on the basis of key studies: Kristeller's Supplementum Ficinianum (Firenze 1937); Kristeller, Randall, The Study of the Philosophies of the Renaissance (Journal of the History of Ideas, vol. II, 1941, 449-496); Kristeller, The Philosophy of Marsilio Ficino (New York: Columbia University Press, 1943); idem, Il pensiero filosofico di Marsilio Ficino (Firenze: Le lettere, 1988). Translations of Ficino's texts after: Jan Białostocki, Myśliciele, kronikarze i artyści o sztuce od starożytności do 1500 (Warszawa: PWN, 1978, vol. I, 469-471); Władysław Tatarkiewicz, Estetyka (vol. III, Estetyka nowożytna, Warszawa: Arkady, 1991, 42-110) and Alicja Kuczyńska, Filozofia i teoria piękna Marsylia Ficina (Warszawa: PWN, 1970). Interpretation of Ficino's letters after Stanley Meltzoff, Botticelli, Signorelli and Savonarola. Theologia Poetica and Painting from Boccaccio to Poliziano (Firenze: Olschki, 1987). This is a major text from the point of view of analysis of mutual relations between Ficino and Savonarola, addressing their impact on politics, literature and arts. It also includes a discussion of Ficino's Apologia contra Savonarolam. The text, which Kristeller recognised as Ficino's genuine manuscript, is moreover commented upon in: G. Savonarola, Selected Writings of Girolamo Savonarola: Religion and Politics 1490-1498 (ed. and transl. Anne Borelli, Maria C. Pastore Passaro, New Haven, CT: Yale University Press, 2006) and in Lucciano Bottoni, Leonardo e l'Androgino. L'eros transessuale nella cultura, nella pittura e nel teatro del rinascimento (Milano: Angeli, 2002); the newest edition with an extensive commentary by Volkhard Wels is A Manuscript of Marsilio Ficino's, Apologia contra Savonarolam (ed. Volkhard Wels, Dallas: Bridwell Library, Dallas, Texas: Bridwell Library, 2006).

The following editions of Savonarola's texts are quoted below: Girolamo Savonarola Prediche e scritti (ed. Mario Ferra, Milano: Hoepli, 1930); Edizione Nazionale delle Opere di Girolamo Savonarola (ed. Roberto Ridolfi, Firenze: wyd.1955); Guida Spirituale, Vita Cristiana (Torino 1952); O Miłości Jezusa i inne pisma, (transl. Agnieszka Kuciak, Warszawa: De Agostini-Altaya, 2004). Of significance were also other translations and editions of texts: G. Savonarola, Apologetico: indole e natura dell'arte poetica, (ed. Antonio Stagnitta, Roma: Armando, 1998); G. Savonarola, 
Selected Writings of Girolamo Savonarola... (ed. and transl. Anne Borelli, Maria C. Pastore Passaro). I moreover quote Prison meditations (introduction Luigi Lazzerini, transl. Włodzimierz Olszaniec, Kęty: M. Derewiecki, 2010); this somewhat faulty study was referenced due to the fact that this is the most recent translation of this text by Savonarola.

Of utmost importance for the topic at hand is Polish relevant literature, which extensively addresses the complex philosophical questions of the $15^{\text {th }}$ century: S. Swieżawski, Dzieje filozofii europejskiej w XV wieku (vol. I-VI, Warszawa: Akademia Teologii Katolickiej, 1983) and by the same author, Między średniowieczem a czasami nowymi. Sylwetki myślicieli XV wieku (Warszawa: Znak, 1983) and W. Tatarkiewicz, Historia filozofii (vol. II, Filozofia nowożytna, Warszawa: PWN, 1978) and by the same author, Historia estetyki (vol. III, Estetyka nowożytna, Warszawa: Estetyka Nowożytna, 1991).

The general backdrop of the questions raised here is drawn on the basis of Botticelli from Lorenzo the Magnificent to Savonarola (ed. Daniel Arasse, Florence 2004); J. Białostocki, Myśliciele, kronikarze i artyści o sztuce od starożytności do 1500 (vol. I, Warszawa: PWN, 1978); J. Burchardt, Kultura Odrodzenia we Wtoszech (Warszawa: Państwowy Instytut Wydawniczy, 1991); A. Chastel, Marsile Ficin et l'art (Genève-Lille: Droz, 1954); by the same author, Arte e Umanesimo a Firenze al tempo di Lorenzo il Magnifico (Torino: Einaudi, 1974); E. Garin, Scienza e vita civile nel Rinascimento italiano (Bari: Laterza, 1965); by the same author, Filozofia Odrodzenia we Wtoszech (Warszawa: PWN, 1969); J. Hale, Encyclopaedia of the Italian Renaissance (London: Thames and Hudson, 1989); J. Klaczko, Juliusz II (Warszawa: Wydawnictwa Artystyczne i Filmowe, 1965); G. Pico della Mirandola, De hominis dignitate (ed. E. Garin, Firenze: Vallecchi Editore, 1942); A. Ostrowski, Savonarola (Warszawa: Państwowy Instytut Wydawniczy, 1974); G. Vasari, Żywoty najsławniejszych malarzy, rzeźbiarzy $i$ architektów (transl. K. Estreicher, Warszawa-Kraków: PWN, 1985); D. Weinstein, Savonarola e Firenze (Bologna: Il Mulino, 1970).

The relations between Ficino and Savonarola form a chain of surprising similarities and contradictions, which concerned both the sphere of private life and public activity, issues of religion, morality, spirituality, philosophy, art and politics. 
Both Ficino and Savonarola were born in the families of doctors working at the service of eminent Italian families reigning in Italy. ${ }^{3}$ This is a significant fact, because physicians at that time should be viewed rather as sagesphilosophers, holders of knowledge about humans accumulated for generations, and to a lesser extent as practicing physicians, whose tasks remained in the hands of barber-surgeons. The real scientists of this time were excellent Italian doctors: first of all Ficino himself, doctor and son of a doctor, exponent of all that is best in Italian medicine, but also Jacopo da Forlì, Hugon Benzi from Siena-commentators of Galen, Michele Savonarolaauthor of many learned books and grandfather of Girolamo, Antonio Benivieni, Leone Ebreo and others. ${ }^{4}$ It was believed that therapy is a process which requires extensive and complex knowledge about human nature the human body, as well as about the entire universe. The physician should have an understanding of everything that affects the disposition of the human body, know the properties of minerals, herbs and animal bodies, as well as astral influences, physics, alchemy, botany, zoology, and astrology, and above all the psychophysical nature of man, in order to be a master of the art he practices. ${ }^{5}$ The trend of appreciation of the bodily element, very dynamic, especially in Italians, came out of the circle of humanists, not without a significant participation of the doctors present in this circle.

Numerous praises of the body were proclaimed. Ficino and Manetti were convinced that the human body is more perfect than the animal body and fully prepared to host such a dignified spirit as the human soul. ${ }^{6}$ Michele Savonarola expressed a similar admiration for the human body and its individual organs, emphasizing also the perfection of human dimensions and proportions. $^{7}$ To some extent, these views also had to influence the young

\footnotetext{
${ }^{3}$ Ficino was born in 1433 as the son of Diotifeci d'Angolo di Giusto, a physician of Cosimo Medici. See Alicja KuCZYŃsKA, Filozofia i teoria piękna Marsylia Ficina (Warszawa: PWN, 1970),12-13. Savonarola was born in 1452in Ferrara, where his family moved from Padua when Girolamo's grandfather, Michele Savonarola, was appointed to the court of Nicolo III d'Este, the Marquis of Ferrara. See Norbert HugEdÉ, Savonarola i Florentyńczycy (Warszawa: PAX, 1988), 7; Alison Brown, [Introduction], in Selected Writings of Girolamo Savonarola: Religion and Politics 1490-1498, ed. Anne Borelli, Maria Pastore Passaro (New Haven, CT : Yale University Press, 2006), XV.

${ }^{4}$ Stefan SwIEŻAwski, Dzieje filozofii europejskiej XV wieku, vol. VI (Warszawa: Akademia Teologii Katolickiej, 1983),157.

${ }^{5}$ Ibid. 159.

${ }^{6}$ Giannozzo Manetti (1396-1459) was an eminent Florentine humanist, the author of: De dignitate et exellentia hominis libri IV (1452-1453).

${ }^{7}$ Stefan SwIEŻawski, Dzieje filozofii, vol. VI, 182-183.
} 
Girolamo, whose education was personally led by his eminent grandfather. ${ }^{8}$ He taught him Scripture, the philosophy of St. Thomas Aquinas and directed his university education. ${ }^{9}$ It can be assumed that Michele's grandson knew well his grandfather's knowledge and views.

Both Ficino and Savonarola were close friends with Pico della Mirandola, an outstanding humanist, whose Oration on the Dignity of Man from 1486 was widely known and commented upon. It is difficult to overestimate the influence the text exerted and the way in which it influenced the imagination of the contemporaries. Looking at the scene of Adam's Creation in the Sistine Chapel, one could describe it with the words which, according to Pico, the Supreme Creator addressed to Adam:

\begin{abstract}
The nature of all other creatures is defined and restricted within laws which We have laid down; you, by contrast, impeded by no such restrictions, may, by your own free will, to whose custody We have assigned you, trace for yourself the lineaments of your own nature. I have placed you at the very centre of the world, so that from that vantage point you may with greater ease glance round about you on all that the world contains. We have made you a creature neither of heaven nor of earth, neither mortal nor immortal, in order that you may, as the free and proud shaper of your own being, fashion yourself in the form you may prefer. It will be in your power to descend to the lower, brutish forms of life; you will be able, through your own decision, to rise again to the superior orders whose life is divine. ${ }^{10}$
\end{abstract}

The picture of the human nature as depicted in the Oration on the Dignity of Man, arising from the conviction of the high status of the human person, his exceptional physical, intellectual and spiritual capabilities, is present in both the writings of Ficino and Savonarola. The views of both of them developed in circles of educated patrician elites. Ficino's father, like Savonarola's grandfather, was a court medic of the most eminent Italian families. Cosimo Medici himself had a decisive influence on Ficino's education; he also commissioned the young philosopher to translate Plato's works and made him the head of the Platonic Academy. After Cosimo's death, his son Piero and grandson Lorenzo took care of Ficino and the Platonic Academy.

\footnotetext{
${ }^{8}$ This continued till Michele Savonarola's death in 1468, when Girolamo was 14 years old.

${ }^{9}$ Norbert Hugedé, Savonarola, 7-8.

${ }^{10}$ Giovanni Pico della Mirandola (1463-1494) wrote Oration on the Dignity of Man (De hominis dignitate) in 1486. It was a preface to 900 theses concerning the entire human knowledge, which he formulated to encouragedebate on them among all contemporary scholars. He conceived an idea to organise a large universal congress of all philosophers. He believed that it would allow scholars to adopt a shared position and to create a single, universal philosophy. Giovanni Pico Della Mirandola, De hominis dignitate, ed. Eugenio Garin (Firenze: Vallecchi, 1942),102-122.
} 
One can safely say that Ficino was a household member and friend of three generations of the House of Medici, as well as the intellectual pillar of their closest circle. Villa Careggi, near Florence, donated to the Platonic Academy by Cosimo Medici, was a meeting place and a platform for an exchange of views of outstanding thinkers and artists. The core of this group, apart from its leader and principal theorist Marsilio Ficino and Lorenzo il Magnifico himself, was made up of their distinguished friends.

Savonarola grew up at the court of the d'Este family in Ferrara and had the opportunity to meet both Prince Borso d'Este and his brother Ercole, a famous connoisseur, art collector, owner of an impressive library and patron of artists. The d'Este family, apart from the Medici, famous for their artistic patronage, belonged to the group of well-educated ruling Italian families which supported the arts and enjoyed sophisticated entertainment. ${ }^{11}$

Both Ficino and Savonarola knew very well the court elites, yet this familiarity led them to divergent choices. Ficino for a long time was a household member of the House of Medici. He took advantage of their generosity. He felt great in the company of an educated, sophisticated and influential elite, devoted to philosophical disputes. According to Burckhardt, the charm that the Medici, especially Cosimo and Lorenzo, exerted on their contemporaries relied on their crafty politics as much as on their leading position in the culture of that time. It was Cosimo who instilled in his environment the conviction that Platonic philosophy is the most beautiful manifestation of ancient thought, contributing to its rebirth within humanism. Ficino might have considered himself to be Cosimo's spiritual son. He remained faithful to the Medici until the end, also after their political fall and the expulsion from Florence of Lorenzo's successor and son Piero.

Savonarola broke off contacts with the court in Ferrara early on, and as a committed republican, he expressed a firm belief that all evil in social life stems from restrictions on the freedoms, liberties and rights of citizens. Consequently, he did not hide his hostile attitude towards the "tyranny" of the Medici oligarchy in Florence. ${ }^{12}$

\footnotetext{
${ }^{11}$ Ercole I d'Este contributed significantly to the growth of Ferrara. He developed the city after the designs of Biaggio Rosetti, employed numerous painters, including Ercole Roberti. He was a patron of vocal music and theatre and gathered an extensive library. His children were thoroughly educated and at their time Beatrice Sforza, Izabella Gonzaga and Cardinal Ippolito made a name for themselves as art collectors and patrons. John R. HALE, Encyclopaedia, 126; Jacob BURCHARDT, Kultura Odrodzenia, 48-53.

${ }^{12}$ Stefan Swieżawski, Między średniowieczem a czasami nowymi, Sylwetki myślicieli XV wieku (Warszawa: Znak, 1983), 101; Girolamo Savonarola, Kazanie XIII nad Aggeuszem, in Selected Writings of Girolamo Savonarola,152.
} 
He wrote in the treatise On Contempt for the World (De contemptu mundi) as follows:

"Whoever, on the contrary, takes away the property of the poor, orphans and widows, is simply cunning; wise is the one who collects money; respected is that who can find a cunning word with greater shrewdness." ${ }^{\prime 3}$ This is a clear allusion to Lorenzo il Magnifico, who took money earmarked for dowries for the poor and orphans from the city coffers. Savonarola thus became a part of the current contestation of the existing reality, shared by other citizens of the city, aware of the changes taking place, resulting in a crisis of freedom. The dialogues of Alamann Rinuccini, for example, bear witness to this view. ${ }^{14}$ According to E. Garin his De libertatem is a condemnation of Lorenzo de Medici, full of pain and suffering. Rinuccini's ideal was a harmonious combination of active and contemplative life, with freedom being an inalienable precondition for such action. Only in a free society can man fully express himself. But not in Florence anymore, where the tyrant Medici entangled the citizens with a network of lies. And they had to choose between moral depravity, at the price of which public offices can be held, or else had to leave the city. ${ }^{15}$ When there is no political freedom, a person secludes himself and searches for the freedom of the wise man. In this way, the transition from the Socratic concept of philosophy, focused on man and his earthly life, to the increasingly popular Platonic tradition takes place. In Florence, when Savonarola launched his last fervent assault on a tyranny that "distorts and sterilizes everything," Ficino seemed to be looking for a safe haven in an extraterrestrial sphere, where he could find shelter from the storms of the world. ${ }^{16}$

\footnotetext{
${ }^{13}$ Girolamo Savonarola, O Miłości Jezusa i inne pisma, transl. Agnieszka Kuciak (Warszawa: De Agostini: Altaya, 2004),76.

${ }^{14}$ Alamanno Rinuccini (1426-1499) was born into a patrician family that played an important role in Florence since the 14th century. He was an eminent humanist, studied philosophy under Argyropoulos and translated texts from Greek into Latin. He made a significant contribution to the revival of philosophy in Florence. He belonged to a political camp countering the domination of the Medici, which resulted in the marginalisation of his person in public life, despite his outstanding personal qualities.

${ }^{15}$ Eugenio GaRIN, Filozofia Odrodzenia we Wtoszech (Warszawa: PWN, 1969),114.

${ }^{16}$ Ibid., 115. In his opinion Garin leaves out the fact that Ficino in behind-the-scenes efforts to re-establish the position of the Medici in Florence and, above all, in the fight against the influence of Savonarola. This fact is described by: Stanley Meltzoff Botticelli, Signorelli and Savonarola. Theologia Poetica and Painting from Boccaccio to Poliziano (Firenze: Olschki, 1987), 74-88; Marsilius FICINO, Apologia contra Savonarolam, in: Selected Writings of Girolamo Savonarola, 358 .
} 
Savonarola zealously tried to transform reality by actively participating in the life of Florence and the Church. His sermons, which were relentless tirades against the greed of the clergy, the corruption of customs and unrighteous governments, attracted such large crowds of listeners that they were moved to the cathedral of Santa Maria del Fiore. When in 1491 he became the prior of the Monastery of San Marco, as Burchardt writes:

This man, all out of fire and flame, is about to perform an even greater miracle; his own Dominican monastery and then all the monasteries of this house in Tuscany are enkindled by his spirit and voluntarily carry out a great reform. ${ }^{17}$

After the fall of the Medici rule and the entry of French troops into Florence, it was Savonarola who persuaded the commander of the French army, King Charles VIII, to save the city and take action for the renewal of the whole Church. Since then, the monk, a political idealist, became the informal head of the reborn Republic of Florence and its unquestionable moral authority. Savonarola was a great advocate of civil liberties. He analysed the forms and rules of government, a testimony to which can be found in his sermons, in which he precisely and thoroughly discusses the superiority of republican governments over individual governments. ${ }^{18} \mathrm{He}$ also considered the advantages of different models of the republic, and he was particularly interested in the Venetian model. ${ }^{19}$

He imposed strict moral standards on citizens. Their observance was supervised by a specially appointed militia. He was also involved in reforming the system of government, which was to be civic and free from all tyranny. ${ }^{20}$ According to his prophecies, Florence was called to become a New Jerusalem, in which Christianity was to be reborn. ${ }^{21}$ Led by their prophet, the citizens of Florence called Christ the king of Florence. ${ }^{22}$

\footnotetext{
${ }^{17}$ Jacob BURCHARDT, Kultura Odrodzenia, 288.

${ }^{18}$ In Sermon XIII on Aggeus (12 December 1494), Savonarola speaks to what extent the rule of the individual must be subordinate to the rule of the group (in: Selected Writings,151, 152).

${ }^{19}$ Sermon XIII on Aggeus, 162.

${ }^{20}$ Written rules of governance from the time of Gonfaloniere Giuliano Salviati can be found in Selected Writings, 176-206.

${ }^{21}$ Savonarola addresses this at length in Sermon XIII on Aggeus, 28 December 1494 (Florence, God Has Chosen this City). Selected Writings,163-175.

${ }^{22}$ This took place in 1494, after the republican system was reinstated in Florence. Norbert Hugedé, Savonarola, 138-147. In Sermon XIII on Aggeus, Savonarola speaks directly about Christ being the king of Florence (Selected Writings, 170-172). In his Pal Sunday sermon in
} 
However, it was not so much Savonarola's reforms of morality but his efforts to convene a council of the Church, his desire to reform the Church and first and foremost the deposition of Pope Alexander VI Borgia which led to his death at the stake in $1498 .^{23}$ The Dominican friar was in open conflict with Alexander VI Borgia, whom he found unworthy of sitting on the throne of St. Peter and called his papacy a divine punishment. ${ }^{24} \mathrm{He}$ did not hesitate to accuse him of betraying the Church and being immoral, using very harsh language..$^{25}$

Savonarola worked actively for the reform of the Church, much as other $16^{\text {th }}$-century reformers, e.g. Luther and Calvin, ${ }^{26}$ while Ficino was above all a theoretician, a philosopher who remained a beneficiary of the existing system, whose operation he did not question. Both Ficino and Savonarola were well-educated people with broad intellectual horizons and a considerable literary output. As Catholic priests, they felt especially called to defend their religion. The fact of pursuing this goal in a divergent and mutually exclusive way was, I think, one of the most serious sources of conflict between them.

Ficino the humanist, a philosopher, fascinated by neo-Platonic thought, wanted to convert people using arguments taken from philosophy. Working on the renewal and restoration of the Platonic doctrine, he saw this as the purpose of his life and considered himself an instrument of divine providence. ${ }^{27}$ In a letter to his friend Pico della Mirandola he glorified platonic knowledge as a fisherman's net which he casts out to capture the minds of

1497, Savonarola calls Florence a New Jerusalem and evokes the rule of the city's king-Jesus Christ (Ibid., 235).

${ }^{23}$ Information on Savonarola from: Mario FERRARA, "L'influenza del Savonarola sulla letteratura e l'arte del quattrocento," in Girolamo Savonarola Prediche e Scritti, ed. MarioFerrara (Milano: Hoepli, 1930); Eugenio GARIN, Filozofia Odrodzenia we Wtoszech (Warszawa: PWN, 1969); Adam Ostrowski, Savonarola; Stefan SwIEŻAwski, Dzieje filozofii; IDEM, Między średniowieczem a czasami nowymi, 100-104; Stanley Meltzoff, Botticelli, Signorelli and Savonarola; John R. HALE, Encyclopaedia of the Italian Renaissance, 291; Selected Writings, 261-310.

${ }^{24}$ He speaks about it at length in Dialogue on Prophetic Truth (1496-1497). Selected Writings, 109. A clear picture of opposition to the Pope was preserved in the letters exchanged between the Holy See and Savonarola in 1495-1498. In them the preacher confronts his moral authority and the prophetic gift against the entire power of the Church Institution under the authority of Alexander VI Borgia. Threatened with excommunication, he decided to "make his opinions public" by writing open letters (to friends-1495, to all believing Christians-1497). Selected Writings, 261-310.

${ }^{25}$ Paweł Lisicki, [Introduction], in Girolamo Savonarola, O miłości Jezusa, 8-9.

${ }^{26}$ This is how Savonarola' a activity is defined by G. Mazzotta ([Foreword], in Selected Writings, XI).

${ }^{27}$ Paul O. KRISTELLER, Il pensiero filosofico di Marsilio Ficino (Firenze: Le lettere, 1988), 346. 
non-believers and converts them to the Christian faith. ${ }^{28}$ In antiquity, in texts by Hermetics, and first of all in Plato and Plotinus, Ficino sought a confirmation of the thesis that there is a single, non-contradictory school of ancient theology. He sought to reconcile the doctrine of the Church with the pre-Christian tradition. He saw the cause of evil in the lack of spiritual life, contemplation and wisdom, and regarded will and intellect as the most powerful engines of our internalization. ${ }^{29}$

Savonarola saw philosophy as an obstacle to the development of faith. He said straightforwardly that faith was spreading faster before numerous reasoned arguments appeared. He longed to renew the Church and restore the simplicity of the first Christians. This is what his prayer for the Church sounds like:

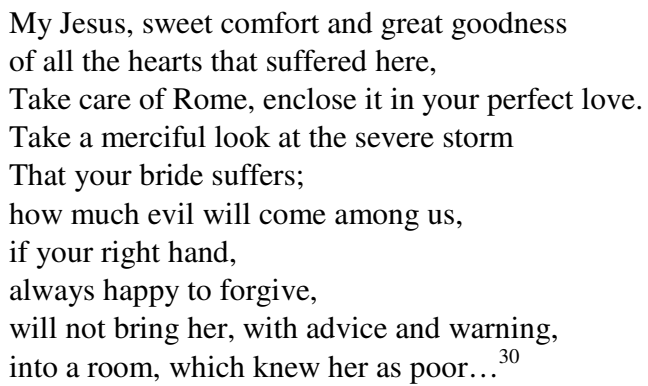

The preacher was a great advocate of mental prayer and inner contemplation; many of his reflections are filled with mysticism. ${ }^{31}$ His goal was to convert and persuade sinners to repentance and to renew the Church, feeling called to do so by God. ${ }^{32}$

In the face of such far-reaching differences, a dispute arose around a seemingly peripheral problem of astrology. The revived astrological practices were particularly popular in Italy and were considered an important field of knowledge. ${ }^{33}$ Ficino was interested in the influence of planets on human life and saw the possibility of using astrology in medicine. He considered

\footnotetext{
${ }^{28}$ Ibid., 348.

${ }^{29}$ Stefan Swieżawski, Między średniowieczem, 217.

${ }^{30}$ Girolamo Savonarola, Modlitwa za Kościót, in IDEM, O miłości Jezusa, 23.

${ }^{31}$ IDEM, Na obronę i pochwate modlitwy myślnej, 103-129.

${ }^{32}$ Jacob BuRChARDT, Kultura Odrodzenia, 290-293; Paweł LisicKI [Introduction], in Girolamo Savonarola, O mitości Jezusa, 10.

${ }^{33}$ Stefan SwIEŻawski, Dzieje filozofii, vol. VI, 253-54.
} 
astrology to be a knowledge higher than the gift of prophecy. ${ }^{34} \mathrm{He}$ set up horoscopes for the children of the House of Medici, and predicted that the small Giovanni, later Leo X, would become a pope. ${ }^{35}$ Ficino was moreover an author of a treatise on astrology titled De vita coelitus comparanda and its third part De triplici vita, concluding two earlier parts, dedicated to philosophical and medical matters. ${ }^{36}$ In Italy Ficino was regarded as the main advocate and defender of astrology, who played an important role in polemics with the opposite camp, whose main mentor was Savonarola, the author of an anti-astrological treatise L'astrologia divinatrice. ${ }^{37}$

The member of the Order of Preachers was an adamant opponent of astrology and censured it e.g. with limiting human freedom. ${ }^{38}$ He spoke about impia astrologia: non é da disputar (con loro) altrimenti che col fuocothey are not to be debated with other than with fire, showing for them a place at the stake. ${ }^{39}$ In turn, the prior of San Marco saw himself as a prophet, much like the prophets of the Old Testament, sent to Florence by God to warn and convert the city by prophesying its future fate. ${ }^{40}$

In the thirteenth book of Teologia Ficino points out that among the people who are temporarily disconnected from their bodies there are bards and prophets. Still, they are among the last of such people, and he indicates that their prophecies arise without art and reflection, while astrologers and diviners are based on complete intellect. He points to the prophecies of ancient bards and sybils, to the biblical prophets, to the testimonies of Platonic philosophers and to the dream experience. ${ }^{41}$

There was a fundamental and profound dispute between those who, in addition to natural predictions, accepted the supernatural gift of prophecy as a source of foretelling the future-and those who tried to translate all prophecy as a manifestation of astral influences, and thus as a phenomenon that was basically natural. The inspired representative of the first position was Savonarola, who acknowledged the

\footnotetext{
${ }^{34}$ Paul O. KRISTELLER, Il pensiero filosofico, 336-337.

${ }^{35}$ See Jacob BurChard, Kultura Odrodzenia, 312.

${ }^{36}$ All the three parts came out together in Florence in 1489 , but it was De vita coelitus comparanda that was sent by Ficino to Hungary to King Matthias Corvinus. Stefan SwIEŻAwSKI, Dzieje filozofii, vol. VI, 255.

${ }^{37}$ Ibid., 255.

${ }^{38}$ IDEM, Między średniowieczem, 101.

${ }^{39}$ Jacob BUR CHARDT, Kultura Odrodzenia, 386, note 47.

${ }^{40}$ Savonarola wrote a separate treatise De veritate profetica, where he proved that God was still dispatching to the earth, as he did in Judea in the past and he himself felt one of the chosen ones. See Julian KLACZKo, Juliusz II (Warszawa: Wydawnictwa Artystyczne i Filmowe, 1965), 284-285.

${ }^{41}$ Paul O. KRISTELLER, Il pensiero filosofico, 336-337.
} 
divine and demonic (angelic and devilish) sources of prophecy, and who prompted Pico to undertake a vociferous criticism of astrology. ${ }^{42}$

Savonarola encouraged Pico to write a great work Contra hostes Ecclesiae. Its first part was the Disputationes adversum astrologiam divinatricem. ${ }^{43}$ Along with the Disputationes their summary by Savonarola came out in 1495. This testifies to the harmonious and deliberate cooperation of the philosopher with the prior of San Marco. Pico took up his polemic from the position of defending religion and freedom. He also rejected the view that attributed astrological sympathies to Greek philosophers. He accused astrology of questioning God's omnipotence and censured its destruction of the freedom of will and its inaccurate judgments. The defence of freedom was one of the main reasons for his scathing criticism of astrology. At the end of his short life, Pico was as zealous in defending human freedom as he was in his first writings. ${ }^{44}$ A strong belief in the key importance of freedom for the essence of humanity is shared by Pico and Savonarola.

The consequences of the attack on astrology could have affected Ficino, at whom Pico's criticism was directed. Probably wanting to protect his friend, Pico, denouncing his tendency to superstition, tried to show that in reality Ficino is the enemy of astrology, which he defends only because of its services to medicine. ${ }^{45}$ Ficino, who plays the role of a defender of astrology and promotes astrological medicine, definitely distanced himself from various exaggerations and distortions of astrological knowledge. At one time he and Pico della Mirandola wrote a letter against the abuses of astrology. He wrote an outline of a treaty in defence of freedom and Providence, which he never published, though. ${ }^{46}$ The opinion perpetuated by Pico's Disputationes, seeing Ficino as the main protector of astrological superstitions, was in effect unfounded and "probably completely unintended by Pico." 47

Ficino was struck in his soft spot. His astrological treatise De vita coelitus comparanda had already caused him trouble and was the grounds for his accusation against Pope Innocent VIII. ${ }^{48}$ Despite Pico's efforts to point out

\footnotetext{
${ }^{42}$ Stefan SwIEŻAwski, Dzieje filozofii, vol. VI, 262.

${ }^{43}$ Disputationes was the last text by Pico, written in 1489 and published in 1495. See Stefan SwIEŻAWSKI, Dzieje filozofii, vol. VI, 285.

${ }^{44}$ Ibid., 286-287; Jacob BURCHARDT, Kultura Odrodzenia, 312-313.

${ }^{45}$ Stefan SwIEŻAwsKi, Dzieje filozofii, vol. VI, 287.

${ }^{46}$ This took place ca. 1477. See Stefan SwIEŻAwski, Dzieje filozofii, vol. VI, 292.

${ }^{47}$ See ibid., vol. VI, 292.

${ }^{48}$ IDEM, Między średniowieczem a czasami nowymi, 209.
} 
the noble motives for his friend's interest in astrology, Ficino was somehow marked as the leader of the opposing camp. Savonarola, who at one stroke weakened Ficino's position and won over to his camp an outstanding mind such as Pico's, might have been interested in this.

The acrimony of the dispute indicates its personal character. We are probably dealing here with a clash of the prophet and an astrologer concerning the primacy of the sources of their inspiration; this is, then, a struggle for authority over the minds, or rather over the souls of the faithful.

Leading humanists were among the followers and friends of both Ficino and Savonarola. The example of Pico ella Mirandola, a friend of Savonarola's and at the same time spent a significant part of his life in the environment of the Platonic Academy, is very significant. ${ }^{49}$ With time, he succumbed so much to his influence that, following the teachings of the monk, he gave away his possessions and put on the Dominican habit on his deathbed. ${ }^{50}$ This happened in a broader context: "the group of Savonarola supporters, with whom Pico was increasingly closely associated, was in some respects very close to Ficino's school and even connected to it through a deep religious commitment." ${ }^{51}$ Giovanni Nesi, a neo-Platonian, a disciple of Ficino's, was a member of the piagnoni (weepers) of Savonarola's faction and praised his oratory skill as that of a Socrates of Ferrara. ${ }^{52}$ Savonarola had an impact on the poetry of Girolamo Benivieni and Christophoro Landino. $^{53}$

Against this background, the choices made by the artists seem less surprising. Lorenzo di Credi, associated with the Medici circles, cast his works into the fire during the famous bruciamenti delle vanità. The author of multiple nudi, Baccio della Porta, became a monk in the Monastery of San

\footnotetext{
${ }^{49}$ Władysław TATARKIEWICZ, Historia filozofii, vol. II (Warszawa: PWN, 1978), 12.

${ }^{50}$ Jacob BURCHARDT, Kultura Odrodzenia, 312-313.

${ }^{51}$ Eugenio Garin, Filozofia Odrodzenia, 154.

${ }^{52}$ Ibid., 145-146.

${ }^{53}$ Donald Weinstein, "The Myth of Florence," in Florentine Studies, ed. Nicolai Rubinstein (London: Faber and Faber, 1968), 18-20. Girolamo Benivieni and Christophoro Landino were humanists closely linked to the court of Lorenzo Medici. Christophoro Landino (1424-1492) — a poet and literary critic, left in his Dispitationes Camaldulenses an account of a philosophical debate of neo-Platonians, including conversations of Lorenzo Medici with Alberti on active life (vita attiva) and contemplative life (vita contemplativa) as well as those by Alberti and Ficino about the supreme good. Moreover, contemporaries owed to him a significant commentary to Dante's do Divine Com$e d y$ and the dissemination of the idea of privileging poetry above the liberal arts. Girolamo Benivieni (1453-1542) - a poet and close friend of Pico della Mirandola, like him in time became a devout follower of Savonarola. He translated into Italian Savonarola's Della semplicità della vita cristiana, whose ideas he espoused even after the execution of the preacher in 1498.
} 
Marco. ${ }^{54}$ The phenomenon of the transformation of life and art affected many other artists to varying degrees. ${ }^{55}$ This is all the more understandable because the fanatically devout preacher had not only full philosophical competence, but also extensive aesthetic interests. According to Tatarkiewicz, in Savonarola's sermons or in his treatise The Simplicity of the Christian Life $e^{56}$ one may find more thoughts about beauty and art than in any other humanist. More particularly, Savonarola's thoughts were similar to those of the humanists. He was their ardent opponent in metaphysics and ethics, not in aesthetics. On the subject of art and beauty, the humanist and the prior of San Marco had mostly similar thoughts, typical of their era. ${ }^{57}$

Ficino and Savonarola had a powerful impact on the minds of their contemporaries. Ficino shaped the Florentine elite, had an unquestionable position as the greatest expert on Platonic philosophy, was called the "doctor of souls" and his lectures, which began with the words "Dear Beloved in Plato" attracted crowds of listeners. ${ }^{58}$ Savonarola captivated Florence with his sermons, addressing the most important religious, moral and political issues of his time. He stirred up fierce emotions, which were followed by changes in morals and political system. He owed a special position to his "gift of prophecy," and his prophecies, so many of which came true, aroused fear and respect among the faithful. He predicted God's punishment: the fall of the House of Medici, the arrival of foreign troops and the threat of the city. ${ }^{59}$

\footnotetext{
${ }^{54}$ Giorgio VASARI, Żywoty najstawniejszych malarzy, rzeźbiarzy i architektów, vol. IV, transl. Karol Estreicher (Warszawa-Kraków: PWN, 1985), 75.

${ }^{55}$ Vasari included among Savonarola's followers: Fra Bartolomeo, Botticelli, Lorenzo di Credi, the Della Robbia family, Simone del Pollaiolo called Il Cronaca, Marco Tasso, Baccio of Montelupo, and mentioned Michelangelo in the context of fascination with the preacher's work. These are testimonies of artists belonging to the group of Savonarola's followers, of the decisive changes in life under the influence of his teachings, as well as of profound reflection on the religious and moral message contained in his sermons and writings (they were widely available, as they almost constantly appeared in print in the years 1494-1498).

${ }^{56}$ Della semplicità della vita cristiana is a part of Guida Spirituale, where Savonarola calls for a renunciation of luxury and for a return to the simplicity and modesty of the apostles. De simplicitate Christianae vitae, dedicated to the Duke of Ferrara on 10 January 1496, was published in Latin in Florence on 27 August 1496; its Italian translation came out in October 1497.

${ }^{57}$ Władysław TATARKIEWICZ, Historia estetyki, vol. III: Estetyka nowożytna (Warszawa: Arkady, 1991), 79. I address this topic in more detail in: "Ficino and Savonarola. Two Florentine Voices on Beauty, Simplicity and Art," in Limen expectationis, a commemorative book in memory of Fr. Prof. Zdzistaw Kliś, Kraków 2012.

${ }^{58}$ Alicja KuCZYŃSKa, Filozofia i teoria piękna, 16.

${ }^{59}$ In Dialogue on Prophetic Truth (1496-1497), Savonarola himself talks about the fulfilment of his prophecy concerning the death of Lorenzo de Medici and Pope Innocent and the change of government in Florence, in: Selected Writings, 73.
} 
Sooner or later the "doctor of souls" and the inspired prophet had to clash. In his opposition to Savonarola, Ficino was clearly at a disadvantage. The profoundly believing Christian, understanding all the assumptions of the Dominican's reasoning, generally approved his program of reforms. Many in the circle of Lorenzo de Medici himself, like most Florentines, quickly and enthusiastically supported the preacher. Even Ficino, although he retained all his views, seemed to think that there was a possibility of agreement. His tolerance and conviction, after St. Augustine, that love and mercy are essential to religion, led him to endure attacks and withdraw rather than resist. ${ }^{60}$ Ficino listened to Savonarola's sermons, while Savonarola never mentioned Ficino directly and never indicated his familiarity with his texts, so much commented upon at that time. ${ }^{61}$ There is no written record, either, about a direct meeting of the two. However, in his Apologeticus the preacher refers to vain and inane questions and the moral abuse of the philosopher, whom he unabashedly calls Princeps huius seculi, which first applies to the devil and in this context to seditious thinkers, an evident allusion to Ficino. ${ }^{62}$

Ficino's letters, published on an ongoing basis and in response to the preacher's activity, testify to the escalation of the conflict. The letters became Ficino's weapon in the battle with Savonarola. Ficino wrote them in the form of short essays on a given topic, defending his position on issues of faith, philosophy and art at a time when Florence was under the growing influence of the Dominican prior of San Marco. Ficino, aware of the importance of the content of his letters, collected, titled and published them himself in 1495. The order and choice of the letters to be published was made by Ficino himself, and so they contain exactly the record of the opinion and the version of events he wanted to show. ${ }^{63}$

The first letter dates back to 1491, when Savonarola was already gaining in importance and popularity as a teacher, after he settled in the Dominican monastery in San Marco in Florence in 1490. This was still during Lorenzo's lifetime and the letter addressed to Lorenzo's son Piero de Medici lectures on the neo-Platonic theory of the origins of the different kinds of love and arts inspired by them, the deities who personify them and the talents they be-

\footnotetext{
${ }^{60}$ Stanley Meltzoff, Botticelli, Signorelli and Savonarola, 74.

${ }^{61}$ Ibid., 75; see also Donald WeInSteIn, The Myth of Florence, 81.

${ }^{62}$ Stanley Meltzoff, Botticelli, Signorelli and Savonarola, 75.

${ }^{63}$ Ficino's letters were published outside Florence, in Nuremberg and Venice in 1497, and were quite widely known. These letters come mainly from the time after the death of Lorenzo Medici and the fall of the Medici rule in Florence, when Ficino was deprived of their mighty protectorate. Stanley Meltzoff, Botticelli, Signorelli and Savonarola, 78-86.
} 
stow on people. When this letter was published in 1495, it must have been read as a response to Savonarola's 1491 Apologeticus and an obituary of the late Lorenzo and his son Piero, at that time in exile in Rome. The conviction that poetry inspired by various kinds of divine love is similar to prophecies and mysteries was in clear contradiction to Savonarola's already known opinion that poetry is a lewd itching of the ears, designed to deceive weak minds and to dissuade them from higher truths. Apologeticus did not consist merely of brutal attacks on poetry. It contained many rational arguments, seriously justified and well established in tradition. Savonarola rejected all ancient models of religious poetry and denied poetry its pedagogical function, adopting the position of doctrinal purity of the Christian religion. ${ }^{64}$

Ficino's second letter of 1492, also addressed to Lorenzo and Piero, referred to the value of Plato for Christianity, as indicated by Plotinus, Porphirius and Ficino as the foundation. When it came out in print (1495), it acquired significance as defending Platonism in the Christian world, where its position was already in jeopardy. Through Rome-based Piero and Cardinal Giovanni de Medici and Filippo Valori, Ficino asked the assistance of Pope Alexander VI Borgia.

The third letter, of 10 June 1492, the time of publication of Savonarola's Apologeticus, was addressed to Martinus Uranius, Ficino's confidante. ${ }^{65} \mathrm{Fi}$ cino wrote it within a short time of Lorenzo's death, at a moment of high emotional tension and examination of his conscience. He denies that he entrusted the demons with the spreading of paganism, of which he was accused by the preacher and quoted the long Orphic hymn to show that pagan mysteries are a prefiguration of Christianity. Orphic theology had a special history in Florentine neo-Platonism, in the search for analogies between the legacy of Greek-Roman antiquity, Judaism and Christianity, which was so important for Renaissance syncretism.

The fourth letter, of January 1493, was addressed to Filippo Valori, Florence's spokesman at the Vatican. Ficino wrote about the wish to publish De sole et lumine, addressing the divine light piercing the world, as well as

\footnotetext{
${ }^{64}$ Girolamo Savonarola, Apologetico: indole e natura dell'arte poetica, ed. Antonio Stagnitta (Roma: Armando, 1998), 53. Apologeticus de ratione poeticae artis was written in 1491as a reply to a long letter of a Savonarola adherent, the poet Ugolino Verino, where the latter defended poetry. Savonarola's text was in stark opposition to the significance which neo-Platonians wished to impart to poetry.

${ }^{65}$ Martinus Uranius (Prenninger), an eminent German lawyer, an expert on secular and canon law, studied at the University of Padua, and was tied with the circles of the Platonic Academy in Florence.
} 
mentioned the fight of Poliziano, Pico and Landino against the teaching of the fundamentalist and his primitive theology.

The oft-quoted letter to Paul of Middelburg of September 1492, is recognised as a milestone in the new classification of the arts. It contains a transition from scholastic categories to the notions of the liberal arts. Ficino writes: "Our century, the golden age, brought back to the daylight the neglected liberal arts: grammar, poetry, rhetoric, painting, architecture, music, and the ancient singing of Orpheus's lyre." ${ }^{\prime 66}$ It was no coincidence that the letter was penned shortly after Savonarola's Apologeticus. The famous term "golden age" was coined, then, in the heat of the polemics with the Dominican's scholasticism.

Savonarola began Apologeticus with a general classification of arts and sciences, following Thomas Aquinas and Albert the Great and their reflections on Aristotle. In Savonarola's system, poetry was considered the lowest branch of logic and rhetoric. His attitude to ancient poetry was hostile. One can presume what he thought about the singing of the Orphic lyre, since he did not hesitate to say that even "Christian poetry and enunciation are merely a dishwater for pigs, good only for animal nature." ${ }^{67}$ The idea of poetry was the core of the contention. Poetry as the divine furor, inspired by different kinds of Divine love, was Ficino's point of view. Savonarola, in turn, clearly demonstrated that a Christian state must burn the books and expel poets and philosophers. ${ }^{68}$

Ficino had studied thoroughly the writings of Thomas Aquinas and drew on him in his research on Plato. In his ability to reconcile opposites, he believed that he had reconciled the pagan and Christian worlds in a manner acceptable to both Platonists and Dominicans. A part of the Church, including the papacy, became humanistic, and a part remained scholastic. ${ }^{69}$ Awareness of this conflict existed on both sides.

Savonarola once again emphasized these contradictions, unconditionally quoting all the Dominicans' arguments against poetry, Platonism, paganism and the works of the devil. For him there was only one theology; everything else was $\sin ^{70}$

\footnotetext{
${ }^{66}$ Władysław TATARKIEWICZ, Historia estetyki, vol. III, 107.

${ }^{67}$ Stanley Meltzoff, Botticelli, Signorelli and Savonarola, 86.

${ }^{68}$ Questions concerning poetry are marginal here, and are addressed tangentially only in the context of other subjects.

${ }^{69}$ Landino, Ficino, Poliziano were people of the Church. Stanley Meltzoff, Botticelli, Signorelli and Savonarola, 87.

${ }^{70}$ Ibid.
} 
Ficino's attitude to Savonarola changed within a few years. In his letter of December 1494 to Giovanni Cavalcanti, Ficino admits ${ }^{71}$ that the preacher's prophecies about imminent danger had come true and that it was only thanks to the sanctity and wisdom of Savonarola himself, whom he called God's chosen one, that no disaster had occurred. ${ }^{72}$ However, a few days later, in another letter to Cavalcanti, he quotes Plato and writes that people's characters and future events show whether they are truly endowed with Divine gifts. ${ }^{73}$ These were the last two letters from Ficino's selection and at the same time his last published words until Apologia conra Savonarolam from 1498.

It so happened that in Santa Maria Novella, the fresco depicting Ficino, Landino and Poliziano watching the Angel appear to Zachariah is located near the fresco on which St. Dominic burns the heretical books. ${ }^{74}$ The paintings, representing the Tornabuoni family and other influential Florentines in religious scenes, inspired Savonarola to deliver the most memorable sermon against all the vanities of the world, shown in church paintings. ${ }^{75}$

\begin{abstract}
You have consecrated my temple and my churches to Moloch, your god. Look at the customs of Florence. [...] These are your idols, and you have placed them in my temple. The images of your gods are the images and portraits of the characters you are having painted in churches. Then the young people go and say about this and that woman: This - this is Magdalene, and that-that is St. John, this is Madonna, because you tell them to paint figures in churches in the likeness of this or that woman, which is a very bad deed and a great contempt for God's things. You painters do wrong, and if you knew what mischief that would entail, and what I know, you wouldn't paint them. You place all the mischiefs of this world in the churches. Do you believe that the Virgin Mary would walk dressed in the way you paint her? I am telling you that she was walking around dressed like a poor woman, modestly and covered in such a way that one could hardly see her face. Similarly, Saint Elizabeth walked in modest clothes. You had much better erase the characters painted so obscenely. You make us imagine the Virgin Mary dressed as a harlot. Now, to a large extent, God's worship is corrupt. ${ }^{76}$
\end{abstract}

\footnotetext{
${ }^{71}$ Giovanni Cavalcanti (1444?-1509) was a bosom friend of Ficino's, a member of the Platonic Academy and a poet.

${ }^{72}$ Ficino mentions the salutary role which Savonarola played during the French invasion.

${ }^{73}$ Stanley Meltzoff, Botticelli, Signorelli and Savonarola, 76.

${ }^{74}$ This observation was taken over from Meltzoff (Botticelli, Signorelli and Savonarola, 87).

${ }^{75}$ Ibid., 87-88.

${ }^{76}$ Sermon: [Amos, V, 26] from 1496; Girolamo Savonarola, Prediche e scritti, ed. Mario Ferrara (Milano: Hoepli, 1930), 387. Quoted after B. Gawrońska's translation.
} 
When Savonarola spoke again of burning books, it was remembered that St. Dominic had already done so, as had many others before and after, and that the heretics would be burned along with their books. These humanists were in danger, their lives and works were in danger. They could only be protected by a small group of educated, patrician families who still had influence and power, but who were also in a difficult situation. ${ }^{77}$ The events of 1492-1495 made Ficino fear for both his own life and the fate of his intellectual legacy. ${ }^{78}$

The conflict was growing in line with the ancient tragedy and there was no turning back or finding a compromise solution. It so happened that it was Savonarola who died at the stake on 23 May $1498 .{ }^{79}$ He had earlier lost support in his most potent ally and protector, King Charles VIII of France, who died in April that year. The conflict between the opponents and the supporters of the preacher caused riots in the city, and the government of Florence, which was opposed to the preacher at the time, led to his imprisonment. Savonarola, excommunicated by Pope Alexander VI Borgia, was subjected to cruel court procedures. He was interrogated, tortured and ultimately sentenced to death. ${ }^{80}$

When in prison, he still managed to write Prison Meditations, a touching testament to the power of spirit and faith in Divine mercy. Widely known and commented upon, for the followers they were proof of his holiness, and for the opponents a confession of guilt. They contain confessions of a man in an ultimate situation:

\footnotetext{
${ }^{77}$ Interpretation of the facts was taken over from S. Meltzoff, (Botticelli, Signorelli and Savonarola, 87-88). It should also be noted that Ficino's situation became even more untenable when in 1494, after the death of Lorenzo Il Magnifico (d. 1492), the rule of the Medici was cut short and the city survived the invasion of the French army of Charles VIII. It was then that the best, classic period of the Platonic Academy's activity came to an end, as in 1494, by a strange coincidence, several of its most outstanding members died: Angelo Polizano, Pico della Mirandola and Filippo Vallori. See Stefan SwIEŻAwsKi, Między średniowieczem a czasami nowymi, 207; Norbert HugEdÉ, Savonarola, 125-126.

${ }^{78} \mathrm{He}$ expressed this in a letter to Aldus Manutius (Venice) writing that he feels safe neither in Florence nor in Careggi. Volkhard WeLs, Introduction, in: A Manuscript of Marsilio Ficino's, Apologia contra Savonarolam (Dallas-Texas: Bridwell Library, 2006), 11.

${ }^{79}$ The execution took place in Piazza della Signoria. Savonarola was hanged with his two confreres. Then their bodies were burnt at the stake and the ashes thrown into the River Arno to prevent a possible "worship" of their "relics." John R. HALE, Encyclopaedia, 92; Volkhard WeLS, Introduction, 10; Alison Brown, Introduction, XXX-XXXI.

${ }^{80}$ Adam Ostrowski, Savonarola, 169; John R. HALE, Encyclopaedia, 92; Volkhard Wels, Introduction, 10; Alison Brown, Introduction, XXX-XXXI; Luigi LAZZERINI, Introduction, in Girolamo Savonarola, Medytacje więzienne, transl. Włodzimierz Olszaniec (Kęty: M. Derewiecki, 2010), 9.
} 
Doing good out of love for You, I can withstand all evil. I will not do it thanks to my own power, but I shall call the name of the Lord. I shall fulfil my vows before your entire people, since Precious in the eyes of the Lord is the death of his faithful ones. ${ }^{81}$ Therefore, be my God-protector. Defend me from my enemies. My enemies are my sins, which invoke your righteousness against me. I will not be able to oppose it if you do not defend me. Your mercy, Lord, is my shield, you surround him with the shield of your good will ${ }^{82} \mathrm{I}$ have nothing to offer justice and to appease its anger. ${ }^{83}$

Ficino's reaction to the tragic fall of Savonarola was Apologia Marsilij Ficini, pro Multis Florentinis ab Antichristo Hieronimo Ferrariense, written shortly after the Dominican's death. ${ }^{84}$ While Volkhard Wels claims that the reasons for writing the text may have been many and varied, it is a testament to the ruthless struggle and deep-seated hatred. Wels considers it significant that Ficino wrote on behalf of many citizens of Florence, whom Savonarola had won over. By justifying to the pope the supporters of the preacher, among whom were the philosopher's friends and acquaintances, he wanted to protect them from the reprisals that affected the people close to Savonarola right after his death. ${ }^{85}$ Apologia explained the conduct of fellow citizens with the aim of taking away from them the co-responsibility for the resistance to the Pope and the influence gained by Savonarola in Florence. Perhaps the shifting of the whole problem to the eschatological level of the struggle between good and evil was the only way for Ficino himself to explain the situation.

Addressing his letter to the College of Cardinals, the sophisticated and sensitive neo-Platonist spoke of his opponent, whom he had already seen as evil incarnate:

It is not a mere mortal; it is one of the most cunning demons, not even a single demon, but a whole herd of devils, who harassed the unfortunate mortals with the

\footnotetext{
${ }^{81}$ Ps 116:15; the quote in the New American Bible reads as follows: Precious in the eyes of the Lord is the death of his faithful ones.

${ }^{82}$ Ps 5:13; the quote in the New American Bible reads as follows: For you, o Lord, bless the just man; you surround him with the shield of your good will.

${ }^{83}$ Girolamo Savonarola, Komentarz do Psalmu 31 ("W Tobie, Panie, Poktadatem Nadzieje”), in IDEM, Medytacje więzienne, 59-60.

${ }^{84}$ A Manuscript of Marsilio Ficino's, Apologia contra Savonarolam, 19-23; Marsilius Ficino, Apologia contra Savonarolam, p. 355-358; Luciano BoTTONI, Leonardo e l'Androgino. L'eros transessuale nella cultura, nella pittura e nel teatro del rinascimento (Milano: Angeli, 2002), 42; Stanley Meltzoff, Botticelli, Signorelli and Savonarola,42-52; Paul O. Kristeller, Supplementum Ficinianum (Florence: Olschki, 1937), vol. 1, cxli, vol. 2, 76-79.

${ }^{85}$ Volkhard WELS, Introduction, 12.
} 
most subtle stimuli and led them astray by unusual intrigues ... This antichrist had unparalleled cunning in pretending virtue and concealing his imperfections with perfect perseverance; a broad mind, inexorable impudence, the art of unjustified self-esteem, the pride of the lucifer, the gift of sustaining everywhere his most shameless lies through curses and spells; a face, a tone of voice, a word that often sparkled in the speech, imposing on the listeners a conviction born not so much of persuasion as of violence. ${ }^{86}$

Ficino wrote that Savonarola had led astray many citizens of Florence, yet thanks to St. Francis, the Pope and the Divine providence, Florence was saved from the antichrist. ${ }^{87}$ How deep was the conflict that led Ficino to formulate his thoughts in such a way, how irreconcilable the opponents of the conflict, and how much it must have divided the community of Florence! The dispute of the leading mentors of that time must have caused anxiety among the contemporaries. Ficino and Savonarola are characters similar in their sense of mission, but moving in opposite directions, like an angel and demon circling around a single trunk of the paradise tree of the knowledge of evil and good-in Exile from Paradise, depicted on the vault the Sistine Chapel by Michelangelo.

Both antagonists died within one year of each other and their ideas continued to exert their impact long after their death, finding their reflection in the thoughts and art of the next century. The importance of their conflict for the culture and art of fully-fledged Renaissance is difficult to overestimate.

\section{BIBLIOGRAPHY}

AdRIANI, Maurilio. Firenze Sacra. Firenze: Nardini, 1990.

Bialostocki, Jan. Myśliciele, kronikarze i artyści o sztuce od starożytnosci do 1500 [Thinkers, chroniclers and artists about art from antiquity till 1500]. Warszawa: PWN, 1978.

BotToni Luciano, Leonardo e l'Androgino. L'eros transessuale nella cultura, nella pittura e nel teatro del rinascimento. Milano: Angeli, 2002.

BURCHARDT, Jacob. Kultura Odrodzenia we Wtoszech [Renaissance culture in Italy]. Warszawa: Państwowy Instytut Wydawniczy, 1991.

\footnotetext{
${ }^{86}$ Marsilius Ficino, Apologia, in Selected Writings, 355; Stanley Meltzoff, Botticelli, Signorelli and Savonarola, 77; Paul O. KRISTELLER, Supplementum, vol. 1, cxli, vol. 2, 76-79 (transl. after Norrbert Hugede, Savonarola, 5).

${ }^{87}$ A Manuscript of Marsilio Ficino's, Apologia contra Savonarolam, 19-20; Luciano BotTONI, Leonardo e l'Androgino, 42; Stanley Meltzoff, Botticelli, Signorelli and Savonarola, 342-356; Marsilius FICINO, Apologia, 355.
} 
BURKE, Peter. Kultura i spoteczeństwo w renesansowych Wtoszech [Culture and society in Renaissance Italy]. Warszawa: Państwowy Instytut Wydawniczy, 1991.

Chastel, André. Marsile Ficin et l'art. Genève-Lille: Droz, 1954.

Chastel, André. Arte e Umanesimo a Firenze al tempo di Lorenzo il Magnifico. Torino: Einaudi, 1974.

Eco, Umberto. Sztuka i piękno w średniowieczu [Art and beauty in the middle ages]. Kraków: Znak, 1997.

Enciclopedia Italiana di scienze, lettere ed arti. Milano: Istituto Giovanni Treccani, 1936.

Ferrara, Mario. "L'influenza del Savonarola sulla letteratura e l'arte del quattrocento." In Girolamo Savonarola. Prediche e scritti. Milano: Hoepli, 1930.

FICINO, Marsilius. A Manuscript of Marsilio Ficino's, Apologia contra Savonarolam, edited by Volkhard Wels. Dallas: Bridwell Library, 2006.

GARIN, Eugenio. Scienza e vita civile nel Rinascimento italiano. Bari: Laterza, 1965.

GARIN, Eugenio. Filozofia Odrodzenia we Wtoszech [Philosophy of the Renaissance in Italy]. Warszawa: PWN, 1969.

HaLE, John R. Encyclopaedia of the Italian Renaissance. London: Thames and Hudson, 1989.

HugEDE, Norbert. Savonarola i Florentyńczycy [Savonarola and the Florentians], Warszawa: PAX, 1988.

KLACZKO, Julian. Juliusz II [Julius II]. Warszawa: Wydawnictwa Artystyczne i Filmowe, 1965 [Paris, 1898].

KRISTELLER, Paul O. Supplementum Ficinianum. Florence: Olschki, 1937.

KrISTELLER, Paul O. The Philosophy of Marsilio Ficino. New York: Columbia University Press, 1943.

Kristeller, Paul O. Il pensiero filosofico di Marsilio Ficino. Firenze: Le lettere, 1988.

KuCZYŃSKA, Alicja. Filozofia i teoria piękna Marsylia Ficina [Philosophy and theory of beauty of Marsilio Ficino]. Warszawa: PWN, 1970.

Macchiavelli, Niccolò. Ksią̇ę, Rozważania nad pierwszym dziesięcioksięgiem historii Rzymu Liwiusza [The prince]. Warszawa: Państwowy Instytut Wydawniczy, 1984.

Meltzoff, Stanley. Botticelli, Signorelli and Savonarola. Theologia poetica and Painting from Boccaccio to Poliziano. Firenze: Olschki, 1987.

Ostrowski, Adam. Savonarola.Warszawa: Państwowy Instytut Wydawniczy, 1974.

PANOFSKY, Erwin. Renaissance and Renascences in Western Art. Copenhagen: Russak, 1960.

PANOFSKy, Erwin. Studia z Historii Sztuki [Studies in art history]. Warszawa: Państwowy Instytut Wydawniczy, 1971.

Pico Della Mirandola, Giovanni. De hominis dignitate, edited by Eugenio Garin. Florence: Vallecchi, 1942.

Rovassenda, Enrico. Savonarola: Moralista-Mistico-Proféta, Studi Savonaroliani, vol. I-III. Ferrara: Rovego 1952-1953.

Savonarola, Girolamo. Apologetico: indole e natura dell'arte poetica, edited by Antonio Stagnitta. Roma: Armando, 1998.

Savonarola, Girolamo. Prediche e scritti, edited by Mario Ferrara. Milano: Hoepli, 1930.

SAvonarola, Girolamo. Edizione Nazionale delle Opere di Girolamo Savonarola, edited by Roberto Ridolfi. Roma, A. Belardetti, 1955. 
Savonarola, Girolamo. Guida Spirituale, Vita Cristiana. Torino: R. Berruti, 1952 [1497].

Savonarola, Girolamo. O Mitości Jezusa i inne pisma [On the love of Jesus and other writings]. Translated by Agnieszka Kuciak. Warszawa: De Agostini-Altaya, 2004.

SAvonarola, Girolamo. Selected writings of Girolamo Savonarola: religion and politics 1490-1498, edietd by Anne Borelli, Maria Pastore Passaro. New Haven, CT: Yale University Press, 2006.

Savonarola, Girolamo. Medytacje więzienne [Prison meditations]. Introduction Luigi Lazzerini. Translated by Włodzimierz Olszaniec. Kęty: M. Derewiecki, 2010.

SwIEŻAwsKi, Stefan. Dzieje filozofii europejskiej XV wieku [The history of European philosophy of the $15^{\text {th }}$ century], vol. I-VI. Warszawa: Akademia Teologii Katolickiej, 1983.

SwIEŻAwSKI, Stefan. Między średniowieczem a czasami nowymi. Sylwetki myślicieli XV wieku [Between the middle ages and the modern era. Thinkers of the $15^{\text {th }}$ century]. Warszawa: Znak, 1983.

TATARKIEWICZ, Władysław. Historia filozofii [History of philosophy], vol. I-III. Warszawa: PWN, 1978.

TATARKIEWICZ, Władysław. Historia estetyki [History of aesthetics], vol. III: Estetyka Nowożytna. Warszawa: Arkady, 1991.

VASARI, Giorgio. Żywoty najstawniejszych malarzy, rzeźbiarzy i architektów [The lives of the most excellent painters, sculptors, and architects]. Translated by Karol Estreicher. Warszawa-Kraków: PWN, 1985.

WARburG, Aby. La rinascita del paganesimo antico. Perugia: Sograte, 1987 [Leipzig-Berlin, 1932].

WEISE, Georg. Il rinovamento dell'arte religiosa nella rinascita. Firenze: Sansoni, 1969.

WeinsteIn, Donald. "The Myth of Florence.” In Florentine Studies, edited by Nicolai Rubinstein. London: Faber and Faber, 1968.

WeInSteIn, Donald. Savonarola e Firenze. Bologna: Il Mulino, 1970.

\section{FICINO AND SAVONAROLA \\ TWO FACES OF THE FLORENCE RENAISSANCE}

Summary

Analysis of the mutual relations between the main intellectual and spiritual authority of the Plato Academy - Marsilio Ficino on the one hand, and Girolamo Savonarola, whose activity was a reaction to the secularization of de Medici times on the other, and a thorough study of their argument that turned into a ruthless struggle, are possible on the basis of selected sources and studies of the subject. The most significant are the following: Savonarola, Prediche e scritti; Guida Spirituale-Vita Christiana; Apologetico: indole e natura dell'arte poetica; De contempt mundi as well as Ficino's letters and Apologia contra Savonarolam; and also Giovanni Pica della Mirandoli's De hominis dignitate.

The two adversaries' mutual relations were both surprisingly similar and contradictory. They both came from families of court doctors, which gave them access to broad knowledge of man's nature that was available to doctors at those times and let them grow up in the circles of sophisticated Renaissance elites. Ficino lived in de Medicis' residences in Florence, and Savonarola in the palace belonging to d'Este family in Ferrara. Ficino eagerly used the benefits of such a situation, whereas Savonarola became an implacable enemy of the oligarchy that limited the citizens' 
freedom they had at that time, and a determined supporter of the republic, to whose revival in Florence he contributed a lot. This situated them in opposing political camps.

They were similarly educated and had broad intellectual horizons. They left impressive works of literature concerned with the domain of spirituality, philosophy, religion, literature and arts, and their texts contain fewer contradictions than it could be supposed.

Being priests, they aimed at defending the Christian religion. Ficino wanted to reconcile the religious doctrine with the world of ancient philosophy and in order to do this he did a formidable work to make a translation of Plato's works. He wanted to fish souls in the intellectual net of Plato's philosophy and to convert them. And it is here that they differed from each other. Savonarola's attitude towards the antiquity was hostile; he struggled for the purity of the Christian doctrine and for the simplicity of its followers' lives. He called upon people to repent and convert. He first of all noticed an urgent need to deeply reform the Church, which led him to an immediate conflict with Pope Alexander VI Borgia.

In accordance with the spirit of the era, he was interested in astrology and prepared accurate horoscopes. Savonarola rejected astrology, and he believed that God, like in the past, sends prophets to the believers. His sermons, which had an immense impact on the listeners, were based on prophetic visions, especially ones concerning the future of Florence, Italy and the Church. His moral authority and his predictions that came true, were one of the reasons why his influence increased so much that after the fall of the House of Medici he could be considered an informal head of the Republic of Florence. It was then that he carried out the strict reforms, whose part were the famous "Bonfires of the Vanities."

Ficino only seemingly passively observed the preacher's work. Nevertheless, over the years a conflict arose between the two great personalities. It had the character of political struggle. It was accompanied by a rivalry for intellectual and spiritual influence, as well as by a deepening mutual hostility. Ficino expressed it in Apologia contra Savonarolam written soon after Savonarola's tragic death; the monk was executed according to Alexander VI Borgia's judgment. The sensible neo-Platonist did not hesitate to thank the Pope for liberating Florence from Savonarola's influence and he called his opponent a demon and the antichrist deceiving the believers.

How deep must the conflict have been since it led Ficino to formulating his thoughts in this way, and how must it have divided Florence's community? The dispute between the leading moralizers of those times must have caused anxiety in their contemporaries. Both the antagonists died within a year, one after the other, and their ideas had impact even long after their deaths, finding their reflection in the next century's thought and arts.

Key words: Ficino; Savonarola; Pico della Mirandola; neo-Platonism; art; religion; Renaissance; republic; piagnoni; Apologia contra Savonarolam.

Translated by Marcin Turski

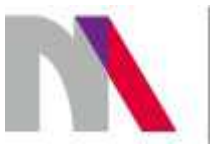

The preparation of the English version of Roczniki Humanistyczne (Annals of Arts) and its publication in electronic databases was financed under contract no. 836/P-DUN/2018 from the resources of the Minister of Science and Higher Education for the popularization of science. 